\title{
Lung vasodilatory response to inhaled iloprost in experimental pulmonary hypertension: amplification by different type phosphodiesterase inhibitors
}

\author{
Ralph Theo Schermuly*, Christiane Inholte, Hossein Ardeschir Ghofrani, \\ Henning Gall, Norbert Weissmann, Andreas Weidenbach, Werner Seeger and \\ Friedrich Grimminger
}

Address: Medical Clinic II/V, Justus-Liebig-University Giessen, 35392 Giessen, Germany

Email: Ralph Theo Schermuly* - ralph.schermuly@innere.med.uni-giessen.de; Christiane Inholte - Christiane.Inholte@innere.med.unigiessen.de; Hossein Ardeschir Ghofrani - Ardeschir.Ghofrani@innere.med.uni-giessen.de; Henning Gall - Henning.Gall@innere.med.unigiessen.de; Norbert Weissmann - Norbert.Weissmann@innere.med.uni-giessen.de;

Andreas Weidenbach - Andreas.Weidenbach@innere.med.uni-giessen.de; Werner Seeger - werner.seeger@innere.med.uni-giessen.de;

Friedrich Grimminger - Friedrich.grimminger@innere.med.uni-giessen.de

* Corresponding author

Published: 20 July 2005

Respiratory Research 2005, 6:76 doi:10.1186/1465-9921-6-76

This article is available from: http://respiratory-research.com/content/6/1/76

(C) 2005 Schermuly et al; licensee BioMed Central Ltd.

This is an Open Access article distributed under the terms of the Creative Commons Attribution License (http://creativecommons.org/licenses/by/2.0), which permits unrestricted use, distribution, and reproduction in any medium, provided the original work is properly cited.
Received: 26 April 2005

Accepted: 20 July 2005

\begin{abstract}
Inhaled prostanoids and phosphodiesterase (PDE) inhibitors have been suggested for treatment of severe pulmonary hypertension. In catheterized rabbits with acute pulmonary hypertension induced by continuous infusion of the stable thromboxane analogue U46619, we asked whether sildenafil (PDEI/5/6 inhibitor), motapizone (PDE3 inhibitor) or 8-Methoxymethyl-IBMX (PDEI inhibitor) synergize with inhaled iloprost. Inhalation of iloprost caused a transient pulmonary artery pressure decline, levelling off within $<20 \mathrm{~min}$, without significant changes in blood gases or systemic hemodynamics. Infusion of 8-Methoxymethyl-IBMX, motapizone and sildenafil caused each a dosedependent decrease in pulmonary artery pressure, with sildenafil possessing the highest efficacy and at the same time selectivity for the pulmonary circulation. When combining a per se ineffective dose of each PDE inhibitor $(200 \mu g / \mathrm{kg} \times \min 8-M e t h o x y m e t h y l-I B M X, I \mu g / k g \times$ min sildenafil, $5 \mu g / k g$ $\times$ min motapizone) with subsequent iloprost nebulization, marked amplification of the prostanoid induced pulmonary vasodilatory response was noted and the area under the curve of $\mathrm{P}_{\mathrm{PA}}$ reduction was nearly threefold increased with all approaches, as compared to sole iloprost administration. Further amplification was achieved with the combination of inhaled iloprost with sildenafil plus motapizone, but not with sildenafil plus 8MM-IBMX. Systemic hemodynamics and gas exchange were not altered for all combinations. We conclude that co-administration of minute systemic doses of selective PDE inhibitors with inhaled iloprost markedly enhances and prolongs the pulmonary vasodilatory response to inhaled iloprost, with maintenance of pulmonary selectivity and ventilation perfusion matching. The prominent effect of sildenafil may be operative via both PDEI and PDE5, and is further enhanced by co-application of a PDE3 inhibitor.
\end{abstract}




\section{Introduction}

Severe pulmonary hypertension is a fatal disease with short life expectancy $[1,2]$. Continuous intravenous administration of prostacyclin was documented to improve exercise capacity and survival in patients with idiopathic pulmonary arterial hypertension (IPAH, formerly primary pulmonary hypertension, PPH) [1,3]. Possible disadvantages of this approach are catheter related septic events and systemic side effects including serious systemic hypotension. In patients with pulmonary hypertension associated with pulmonary fibrosis, systemic administration of vasodilators results in ventilation perfusion mismatch and impairment of arterial oxygenation. Inhalation of aerosolized iloprost, a long-acting prostacyclin analogue, has been shown to cause selective pulmonary vasodilatation in both primary and secondary pulmonary hypertension [4-6]. Long term use of nebulized iloprost was described to improve exercise capacity, event-free survival and hemodynamics in severe IPAH, and this finding was supported by a randomized, controlled phase III study in patients in NYHA class III and IV [7].

The use of aerosolized iloprost for acute pulmonary vasodilatation and putative long-term anti-remodeling effects in severe chronic pulmonary hypertension does, however, demand 6-12 inhalations per day, as the vasodilatory effect levels off within $\sim 60$ min post nebulization. Against this background, recent studies addressed the impact of selective phosphodiesterase (PDE) inhibitors on prostacyclin-induced acute pulmonary vasodilatation, reporting a marked amplification and prolongation of the vasodilatory response to inhaled $\mathrm{PGI}_{2}$ [8]. PDEs are enzymes that inactivate cyclic AMP and cyclic GMP, the second messengers of prostacyclin and NO $[9,10]$. The characterization of the various PDEs currently known has largely profited from the employment of selective PDE inhibitors. Concerning the lung vasculature, the presence of the PDE isoenzymes 1, 3, 4 and 5 in the cytosolic and particulate phases (homogenized human pulmonary artery tissue) has been demonstrated [11].

Phosphodiesterase 1 is $\mathrm{Ca}^{2+} /$ calmodulin dependant and hydrolyzes both cGMP and cAMP. PDE3 does possess high affinity for both cAMP and cGMP, with $\mathrm{V}_{\max }$ for cAMP usually greater than that for cGMP $[9,12]$. PDE4 enzymes are characterized by their high affinity to cAMP, with cGMP representing a very poor substrate. In contrast, PDE 5 is cGMP-specific and was found to be highly expressed in lung tissue $[13,14]$.

Recent clinical data suggest that the PDE $1 / 5 / 6$ inhibitor sildenafil $\left(\mathrm{IC}_{50}\right.$ values $280 \mathrm{nM}, 3.5 \mathrm{nM}$ and $37 \mathrm{nM}$, respectively [15]), which has been approved for the treatment of erectile dysfunction, is an effective pulmonary vasodilator in patients with pulmonary arterial hypertension [16-21].
Based on a very recent positive phase III study, sildenafil has been approved for the treatment of pulmonary hypertension in US. Interestingly, it has been shown that sildenafil synergizes with inhaled iloprost in patients with pulmonary hypertension $[16,22]$. Hitherto no attempt was undertaken to clarify, which of the PDEs addressed by sildenafil is the most relevant for the effect of this agent in the pulmonary circulation, and whether combinations with further selective PDE inhibitors might even enhance the sildenafil effect. To address this issue, systemic application of per se ineffective doses of specific PDE inhibitors in companion with inhalation of iloprost was undertaken in an experimental model of pulmonary hypertension in the present study.

\section{Methods \\ Materials}

8-Methoxymethyl-IBMX (8-Methoxymethyl-3-isobutyl-1methylxanthine) and the thromboxane- $\mathrm{A}_{2}$ mimetic U46619 were supplied by Sigma (Deishofen, Germany). Sildenafil was obtained from Pfizer (Sandwich, UK) and iloprost (Ilomedin ${ }^{\circledast}$ ) was obtained from Schering A.G. (Berlin, Germany). All other chemicals and drug supplies were from standard commercial sources.

\section{Surgical Preparation}

New zealand white rabbits weighing between 2.8 and 3.1 $\mathrm{kg}$ of either sex were anesthetized with a mixture of xylazine and ketamine and anticoagulated with $200 \mathrm{U} / \mathrm{kg}$ heparin [8]. Anaesthesia was maintained by a constant intravenous infusion of xylazine and ketamine through the right peripheral ear vein. Animals were tracheostomized and ventilated using a volume-controlled respirator (cat ventilator, Hugo Sachs Elektronik, March Hugstetten, Germany) with $8 \mathrm{ml} / \mathrm{kg}$ bodyweight and a frequency of $40 \mathrm{~min}^{-1}$. $\mathrm{FiO}_{2}$ was set at 0.5 and a positive endexpiratory pressure of $0.5 \mathrm{mmHg}$ was used throughout. The left A. carotis was cannulated for arterial pressure monitoring and a pulmonary artery catheter ( $4 \mathrm{Fr}$, Braun, Melsungen, Germany) was inserted into the pulmonary artery through the right external jugular vein.

\section{Hemodynamics and blood gases}

Mean pulmonary artery pressure $\left(\mathrm{P}_{\mathrm{PA}}\right)$ and mean aortic pressure $\left(\mathrm{P}_{\mathrm{SA}}\right)$ were continuously recorded with fluidfilled force transducers (Braun, Combitrans, FRG). The level of the left atrium was set to zero. As described previously, pulmonary artery occlusion pressure was measured by gentle forwarding of the catheter to wedge position [23]. Pulmonary and systemic vascular resistances were calculated by standard formulas. As described previously, cardiac output (CO) was calculated by using the Fick principle [8]. Briefly, arterial and venous blood samples (1 $\mathrm{ml}$ ) were stored on ice, and hemoglobin and oxygen saturation were measured using an OSM2 Hemoximeter 
(Radiometer-Copenhagen, Denmark). Oxygen uptake of the animals was measured online (Labotect $\mathrm{O}_{2}$-Controller, Goettingen, Germany).

\section{Nebulization}

Iloprost was nebulized by means of an ultrasonic nebulizer (Pulmo Sonic 5500, DeVilbiss Medizinische Produkte $\mathrm{GmbH}$, Langen, Germany) which produces an aerosol with a mass median aerodynamic diameter (MMAD) of $4.5 \mu \mathrm{m}$ and a geometric standard deviation (GSD) of 2.3. The nebulizer was placed in the inspiratory limb of the ventilation system as described previously [24].

\section{Experimental protocols}

U46619 was continuously infused (dose range 0.5 to 2 $\mu \mathrm{g} / \mathrm{kg} \mathrm{min}$ ) to increase pulmonary artery pressure from $\sim 16$ at baseline to $26 \mathrm{mmHg}$ within $20 \mathrm{~min}$. As described previously, stable pulmonary hypertension is established by this approach [8]. Dose-effect curves of intravenous sildenafil, motapizone and 8MM-IBMX were established after reaching a stable pressure plateau, performing shortterm infusions (10 $\mathrm{min}$ ) with randomized doses of these agents. Hemodynamics and blood gases were measured at the end of the $10 \mathrm{~min}$ infusion period. A total dose of 0.4 $\pm 0.08 \mu \mathrm{g} / \mathrm{kg}$ iloprost, nebulized within a $10 \mathrm{~min}$ aerosolization maneuver, was used throughout all studies with iloprost inhalation. In the group with sole administration of this inhalative agent, the nebulization was performed after reaching a stable pressure plateau. In the combination experiments, the PDE inhibitors were administered intravenously at a dose which by itself did not reduce PAP significantly as short-term infusion (10 $\mathrm{min})$, and iloprost was nebulized subsequently.

\section{Data analysis}

All data are given as means \pm SEM. Differences between the different groups were assessed by use of analysis of variance and Student-Newman-Keuls test for multiple comparisons with a $\mathrm{p}$ value $<0.05$ regarded to be significant.

\section{Results \\ Baseline and U466 I9-induced pulmonary hypertension}

The continuous infusion of $1.3 \pm 0.9 \mu \mathrm{g} / \mathrm{kg}$ min U46619 resulted in a significant increase of pulmonary artery pressure $\left(\mathrm{P}_{\mathrm{PA}}\right)$ to $26 \mathrm{mmHg}$ as compared to $16 \mathrm{mmHg}$ prior to U46619 (Table 1). Cardiac output and mean systemic pressure $\left(\mathrm{P}_{\mathrm{SA}}\right)$ did not change significantly. The pulmonary vascular resistance increased from 275 to 592 dyne/s $\mathrm{cm}^{-5} \mathrm{~m}^{2}$. No significant changes in blood gases were measured as compared to baseline values.

\section{Dose-effect curves of PDE-inhibitors}

Intravenous sildenafil, motapizone and 8MM-IBMX reduced $P_{P A}$ in a dose-dependent manner (Fig. 1A), with the dose-effect curves differing by two orders of magnitude between sildenafil and the two other compounds. As depicted in Fig. 1B, this pulmonary vasodilatation was accompanied by a significant systemic arterial pressure decrease in case of motapizone (dose range $6-600 \mu \mathrm{g} / \mathrm{kg}$ $\times \mathrm{min}$ ) and 8MM-IBMX (dose range $70-1500 \mu \mathrm{g} / \mathrm{kg} \times$ $\mathrm{min}$ ), but not in case of sildenafil (dose range $0.1-10 \mu \mathrm{g} /$ $\mathrm{kg} \times \mathrm{min})$.

\section{Nebulization of iloprost}

Inhalation of $0.4 \mu \mathrm{g} / \mathrm{kg}$ aerosolized iloprost resulted in a significant decrease in U46619-induced pulmonary hypertension, from $25.8 \pm 0.6$ to $22.7 \pm 0.4 \mathrm{mmHg} \mathrm{P}_{\mathrm{PA}}$ immediately after stop of nebulization (Table 1, Fig. $2 \mathrm{a}, \mathrm{b})$. Pulmonary vascular resistance decreased in response to the prostanoid by $18 \%$ (Fig. 3). No significant changes in blood gases, cardiac output and systemic arterial pressure were noted (Fig. 4). Within 18 $\mathrm{min}, 95 \%$ of the U46619-induced $\mathrm{P}_{\mathrm{PA}}$ plateau was reached again. The calculated area under the curve (AUC) was $470 \pm 49$ $\% \Delta \mathrm{P}_{\mathrm{PA}} \times \min ($ Fig. 5)

\section{Combined administration of a per se ineffective intravenous PDE-inhibitors and iloprost nebulization}

In the presence of sub-threshold motapizone $(5 \mu \mathrm{g} / \mathrm{kg} \times$ $\min )$, the iloprost-induced vasodilatation was significantly increased, with a maximum $\mathrm{P}_{\mathrm{PA}}$ drop of $40.6 \pm$ $4.6 \%$ of the U46619-induced pressor response, as compared to $23.8 \pm 2.2 \%$ for sole iloprost nebulization (Fig. 2a). In addition, motapizone enhanced the iloprost induced PVR reduction (37\% versus 18\%) (Fig. 3). Moreover, the duration of the vasodilatory response, defined by $\mathrm{P}_{\mathrm{PA}}$ values below 95\% of the U46619-induced pressure plateau, was significantly prolonged, from $18 \mathrm{~min}$ to 50 min. The AUC was markedly increased to $1351 \pm 192$ $\% \Delta \mathrm{P}_{\mathrm{PA}} \times \min (\mathrm{p}<0.01$; Fig. 5). Comparable efficacy was noted for intravenous sub-threshold sildenafil $(1 \mu \mathrm{g} / \mathrm{kg} \times$ min), which enhanced the maximum $\mathrm{P}_{\mathrm{PA}}$ drop to $36.3 \pm$ $3.6 \%$ of the U46619-induced pressor response and PVR reduction to $27 \%$, prolonged the post-nebulization vasodilatory effect to $50 \mathrm{~min}$, and increased the AUC to $1183 \pm 136 \% \Delta \mathrm{P}_{\mathrm{PA}} \times \mathrm{min}$. The combination of sub-threshold $8 \mathrm{MM}$-IBMX with iloprost again enhanced the maximum $P_{P A}$ and PVR decrease in response to iloprost aerosolization and prolonged the vasodilatation to 50 min, with AUC values ranging at $1206 \pm 177 \% \Delta \mathrm{P}_{\mathrm{PA}} \times$ min. No further amplification of the iloprost induced vasodilation was achieved by combination with subthreshold doses of sildenafil plus $8 \mathrm{MM}$-IBMX with an AUC of $1268 \pm 115 \% \Delta \mathrm{P}_{\mathrm{PA}} \times$ min and an amplification of the iloprost effect on $\mathrm{P}_{\mathrm{PA}}$ decrease of $56.4 \pm 4.0 \%$ (Fig. $2 \mathrm{~b}$ ). In contrast, further amplification was noted for the 
Table I: Summarized data of hemodynamics and blood gases in rabbits with U466 I 9-induced pulmonary hypertension and inhalation of iloprost in the absence and presence of sub-threshold intravenous PDE inhibitors. $\Delta$

\begin{tabular}{|c|c|c|c|c|c|c|c|c|c|c|c|c|c|c|}
\hline & \multicolumn{2}{|c|}{$\begin{array}{l}\text { Control/ } \\
\text { U466 I9 }\end{array}$} & \multicolumn{2}{|c|}{ U466 I 9/Ilo } & \multicolumn{2}{|c|}{ U466 I / /IIo/Sil } & \multicolumn{2}{|c|}{$\begin{array}{l}\text { U466I I /IIIo/ } \\
8 M M-I B M X\end{array}$} & \multicolumn{2}{|c|}{$\begin{array}{c}\text { U466 I } 9 / 110 / \\
\text { Mota }\end{array}$} & \multicolumn{2}{|c|}{$\begin{array}{c}\text { U466 I } 9 / 1 / \mathrm{lo} / \\
8 \mathrm{MM}-\mathrm{IBMX} / \mathrm{Sil}\end{array}$} & \multicolumn{2}{|c|}{$\begin{array}{c}\text { U466 I 9/Ilo/ } \\
\text { Mota/Sil }\end{array}$} \\
\hline & Pre & post & pre & post & pre & post & pre & post & pre & post & pre & post & pre & post \\
\hline $\mathbf{P}_{\mathrm{SA}}, \mathrm{mmHg}$ & $\underset{4}{11 \mathrm{I}} \pm$ & $\begin{array}{c}105 \pm \\
3\end{array}$ & $\underset{3}{111} \pm$ & $\underset{3}{111} \pm$ & $\begin{array}{c}106 \pm \\
3\end{array}$ & $\begin{array}{c}105 \pm \\
2\end{array}$ & $\begin{array}{c}107 \pm \\
2\end{array}$ & $\begin{array}{c}104 \pm \\
4\end{array}$ & $\begin{array}{c}100 \pm \\
3\end{array}$ & \pm 3 & $\begin{array}{l}99 \\
\pm 3\end{array}$ & \pm 2 & $\begin{array}{l}93 \\
\pm 4\end{array}$ & $\begin{array}{l}92 \\
\pm 4\end{array}$ \\
\hline $\mathbf{P}_{\mathrm{PA}}, \mathrm{mmHg}$ & $\begin{array}{l}15.9 \pm \\
0.3\end{array}$ & $\begin{array}{c}25.9 * \pm \\
0.4\end{array}$ & $\begin{array}{c}25.8 \pm \\
0.6\end{array}$ & $\begin{array}{c}22.7^{*} \pm \\
0.4\end{array}$ & $\begin{array}{c}25.7 \pm \\
0.2\end{array}$ & $\begin{array}{c}21.8^{*} \pm \\
0.3\end{array}$ & $\begin{array}{c}24.8 \pm \\
0.7\end{array}$ & $\begin{array}{c}21.1 * \pm \\
0.8\end{array}$ & $\begin{array}{c}27.3 \pm \\
I, 1\end{array}$ & $\begin{array}{c}21.0 * \pm \\
0.6\end{array}$ & $\begin{array}{c}25.0 \pm \\
0.4\end{array}$ & $\begin{array}{c}20.4^{*} \pm \\
0.3\end{array}$ & $\begin{array}{c}24.7 \pm \\
0.4\end{array}$ & $\begin{array}{c}19.3^{*} \pm \\
0.4\end{array}$ \\
\hline $\mathrm{co}, \mathrm{n}$ & $\begin{array}{c}555 \pm \\
23\end{array}$ & $\begin{array}{c}544 \pm \\
38\end{array}$ & $\begin{array}{c}432 \pm \\
27\end{array}$ & $\begin{array}{c}452 \pm \\
25\end{array}$ & $\begin{array}{c}444 \pm \\
19\end{array}$ & $\begin{array}{c}488 \pm \\
35\end{array}$ & $\begin{array}{c}393 \pm \\
24\end{array}$ & $\begin{array}{c}437 \pm \\
29\end{array}$ & $\begin{array}{c}417 \pm \\
21\end{array}$ & $\begin{array}{c}446 \pm \\
15\end{array}$ & $\begin{array}{c}454 \pm \\
27\end{array}$ & $\begin{array}{c}505 \pm \\
30\end{array}$ & $\underset{35}{501 \pm}$ & $\begin{array}{c}555 \pm \\
52\end{array}$ \\
\hline $\begin{array}{l}\text { PAOP, } \\
\text { mmHg }\end{array}$ & $\begin{array}{l}7.2 \pm \\
1.2\end{array}$ & $\begin{array}{c}7.6 \pm \\
0.8\end{array}$ & $\begin{array}{c}8.0 \pm \\
1.1\end{array}$ & $\begin{array}{l}7.3 \pm \\
1.3\end{array}$ & $\begin{array}{c}7.7 \pm \\
0.9\end{array}$ & $\begin{array}{l}7.4 \pm \\
1.1\end{array}$ & $\begin{array}{c}7.7 \pm \\
0.8\end{array}$ & $\begin{array}{l}7.6 \pm \\
1.2\end{array}$ & $\begin{array}{c}6.9 \pm \\
1.3\end{array}$ & $\begin{array}{l}7.3 \pm \\
1.1\end{array}$ & $\begin{array}{l}7.7 \pm \\
1.2\end{array}$ & $\begin{array}{l}7.7 \pm \\
1.1\end{array}$ & $\begin{array}{c}7.8 \pm \\
0.8\end{array}$ & $\begin{array}{l}7.2 \pm \\
1.1\end{array}$ \\
\hline $\begin{array}{c}\text { PVRI, dyne/s } \\
\mathrm{cm}^{-5} \mathrm{~m}^{2}\end{array}$ & $\begin{array}{c}275 \pm \\
34\end{array}$ & $\begin{array}{c}592 * \pm \\
49\end{array}$ & $\begin{array}{c}725 \pm \\
39\end{array}$ & $\begin{array}{l}599 * \pm \\
37\end{array}$ & $\begin{array}{c}713 \pm \\
58\end{array}$ & $\begin{array}{c}519 * \pm \\
44\end{array}$ & $\begin{array}{c}765 \pm \\
67\end{array}$ & $\begin{array}{c}543^{*} \pm \\
63\end{array}$ & $\begin{array}{l}861 \pm \\
64\end{array}$ & $\begin{array}{l}540 * \pm \\
71\end{array}$ & $\begin{array}{c}670 \pm \\
75\end{array}$ & $\begin{array}{c}442 * \pm \\
52\end{array}$ & $\begin{array}{c}593 \pm \\
56\end{array}$ & $\begin{array}{c}383 * \pm \\
61\end{array}$ \\
\hline $\mathrm{P}_{\mathrm{a}} \mathrm{O}_{2}, \mathrm{mmHg}$ & $\begin{array}{c}226 \pm \\
17\end{array}$ & $\begin{array}{c}199 \pm \\
12\end{array}$ & $\begin{array}{c}183 \pm \\
12\end{array}$ & $\begin{array}{c}177 \pm \\
10\end{array}$ & $\begin{array}{c}191 \pm \\
6\end{array}$ & $\begin{array}{c}203 \pm \\
4\end{array}$ & $\begin{array}{c}228 \pm \\
7\end{array}$ & $\begin{array}{c}188 \pm \\
12\end{array}$ & $\begin{array}{c}201 \pm \\
7\end{array}$ & $\begin{array}{c}197 \pm \\
11\end{array}$ & $\begin{array}{c}171 \pm \\
10\end{array}$ & $\begin{array}{c}173 \pm \\
11\end{array}$ & $\begin{array}{c}179 \pm \\
10\end{array}$ & $\begin{array}{c}174 \pm \\
14\end{array}$ \\
\hline $\mathbf{P H}_{\mathbf{a}}$ & $\begin{array}{c}7.42 \pm \\
0.02\end{array}$ & $\begin{array}{c}7.35 \pm \\
0.02\end{array}$ & $\begin{array}{c}7.37 \pm \\
0.03\end{array}$ & $\begin{array}{c}7.32 \pm \\
0.01\end{array}$ & $\begin{array}{c}7.36 \pm \\
0.02\end{array}$ & $\begin{array}{c}7.32 \pm \\
0.02\end{array}$ & $\begin{array}{c}7.41 \pm \\
0.02\end{array}$ & $\begin{array}{c}7.38 \pm \\
0.02\end{array}$ & $\begin{array}{c}7.33 \pm \\
0.01\end{array}$ & $\begin{array}{c}7.31 \pm \\
0.01\end{array}$ & $\begin{array}{c}7.35 \pm \\
0.02\end{array}$ & $\begin{array}{c}7.34 \pm \\
0.02\end{array}$ & $\begin{array}{c}7.33 \pm \\
0.02\end{array}$ & $\begin{array}{c}7.29 \pm \\
0.01\end{array}$ \\
\hline $\mathrm{P}_{\mathrm{a}} \mathrm{CO}_{2} \mathrm{mmHg}$ & $\begin{array}{c}42.7 \pm \\
1.3\end{array}$ & $\begin{array}{c}43.0 \pm \\
3.5\end{array}$ & $\begin{array}{c}41.5 \pm \\
2.0\end{array}$ & $\begin{array}{c}40.7 \pm \\
1.0\end{array}$ & $\begin{array}{c}42.0 \pm \\
4.1\end{array}$ & $\begin{array}{c}45.2 \pm \\
4.0\end{array}$ & $\begin{array}{c}36.2 \pm \\
1.6\end{array}$ & $\begin{array}{c}37.7 \pm \\
1.5\end{array}$ & $\begin{array}{l}44.3 \pm \\
1.2\end{array}$ & $\begin{array}{c}46.2 \pm \\
1.2\end{array}$ & $\begin{array}{c}45.9 \pm \\
1.7\end{array}$ & $\begin{array}{c}47.6 \pm \\
1.4\end{array}$ & $\begin{array}{c}36.9 \pm \\
2.0\end{array}$ & $\begin{array}{c}38.0 \pm \\
1.8\end{array}$ \\
\hline $\mathbf{P}_{\mathrm{v}} \mathrm{O}_{2}, \mathrm{mmHg}$ & $\begin{array}{c}46.7 \pm \\
1.3\end{array}$ & $\begin{array}{l}44.1 \pm \\
2.4\end{array}$ & $\begin{array}{c}39.9 \pm \\
1.7\end{array}$ & $\begin{array}{c}42.6 \pm \\
1.2\end{array}$ & $\begin{array}{c}39.7 \pm \\
2.3\end{array}$ & $\begin{array}{c}44.9 \pm \\
1.4\end{array}$ & $\begin{array}{c}35.8 \pm \\
1.5\end{array}$ & $\begin{array}{c}39.7 \pm \\
2.1\end{array}$ & $\begin{array}{c}40.7 \pm \\
1.64\end{array}$ & $\begin{array}{c}42.7 \pm \\
1.2\end{array}$ & $\begin{array}{c}39.7 \pm \\
2.5\end{array}$ & $\begin{array}{l}44.9 \pm \\
2.6\end{array}$ & $\begin{array}{c}41.8 \pm \\
1.2\end{array}$ & $\begin{array}{c}44.0 \pm \\
1.6\end{array}$ \\
\hline $\mathbf{P H}_{\mathrm{v}}$ & $\begin{array}{c}7.30 \pm \\
0.01\end{array}$ & $\begin{array}{c}7.24 \pm \\
0.02\end{array}$ & $\begin{array}{c}7.34 \pm \\
0.03\end{array}$ & $\begin{array}{c}7.29 \pm \\
0.01\end{array}$ & $\begin{array}{c}7.23 \pm \\
0.02\end{array}$ & $\begin{array}{c}7.20 \pm \\
0.02\end{array}$ & $\begin{array}{c}7.37 \pm \\
0.02\end{array}$ & $\begin{array}{l}7.31 \pm \\
0.03\end{array}$ & $\begin{array}{c}7.28 \pm \\
0.01\end{array}$ & $\begin{array}{c}7.26 \pm \\
0.01\end{array}$ & $\begin{array}{c}7.29 \pm \\
0.02\end{array}$ & $\begin{array}{l}7.28 \pm \\
0.02\end{array}$ & $\begin{array}{c}7.28 \pm \\
0.02\end{array}$ & $\begin{array}{c}7.24 \pm \\
0.01\end{array}$ \\
\hline $\begin{array}{l}\mathrm{P}_{\mathrm{v}} \mathrm{CO}_{2}, \\
\mathrm{mmHg}\end{array}$ & $\begin{array}{c}49.8 \pm \\
0.9\end{array}$ & $\begin{array}{c}54.9 \pm \\
1.2\end{array}$ & $\begin{array}{c}48.9 \pm \\
2.3\end{array}$ & $\begin{array}{c}49.7 \pm \\
1.1\end{array}$ & $\begin{array}{c}59.2 \pm \\
1.6\end{array}$ & $\begin{array}{c}60.6 \pm \\
1.4\end{array}$ & $\begin{array}{c}44.6 \pm \\
2.5\end{array}$ & $\begin{array}{c}44.9 \pm \\
2.5\end{array}$ & $\begin{array}{l}52.4 \pm \\
1.4\end{array}$ & $\begin{array}{c}54.2 \pm \\
1.4\end{array}$ & $\begin{array}{c}53.8 \pm \\
2.0\end{array}$ & $\begin{array}{c}52.9 \pm \\
2.2\end{array}$ & $\begin{array}{c}42.5 \pm \\
2.3\end{array}$ & $\begin{array}{c}45.9 \pm \\
1.6\end{array}$ \\
\hline
\end{tabular}

$\triangle \mathrm{P}_{\mathrm{SA}}$, mean aortic pressure; $\mathrm{P}_{\mathrm{PA}}$, mean pulmonary artery pressure; $\mathrm{CO}$, cardiac output; $\mathrm{PAOP}$, pulmonary artery occlusion pressure; $\mathrm{PVR}$, pulmonary vascular resistance; $\mathrm{P}_{\mathrm{a}} \mathrm{O}_{2}$, arterial $\mathrm{PO}_{2} ; \mathrm{PH}_{\mathrm{a}}$, arterial $\mathrm{pH} ; \mathrm{P}_{\mathrm{a}} \mathrm{CO}_{2}$, arterial $\mathrm{PCO}_{2} ; \mathrm{P}_{\mathrm{v}} \mathrm{O}_{2}$, central venous $\mathrm{PO}_{2} ; \mathrm{pH}_{\mathrm{v}}$, central venous $\mathrm{pH}$; $\mathrm{P}_{\mathrm{v}} \mathrm{CO}_{2}$, central venous $\mathrm{PCO}_{2}$; Ilo, iloprost; Sil, sildenafil; 8MM-IBMX, 8-Methoxymethyl-3-isobutyl-I-methylxanthine; Mota, motapizone. The first two columns give summarized data for all groups. All other columns give pre- and post-iloprost nebulization data in animals undergoing preceding sub-threshold PDE-inhibitor infusion ( $\mathrm{n}=\mathbf{8}$ for each group). Asterisks indicate significant differences between pre and post-aerosolization values $(*$ $=\mathrm{p}<0.05$ ).

combination of inhaled iloprost with sub-threshold doses of sildenafil plus motapizone, which enhanced the $P_{P A}$ drop to $54.6 \pm 3.7 \%$, the PVR drop to $35 \%$ and increased the AUC to $1993 \pm 166 \% \Delta \mathrm{P}_{\mathrm{PA}} \times \min$. In none of the groups, any significant decrease in systemic arterial pressure (Fig. 4) or deterioration of gas exchange (Table 1) was noted.

\section{Discussion}

The inhalation of nebulized prostanoids for treatment of pulmonary hypertension is an approach targeting selective vasodilatation in well ventilated and aerosol accessible lung regions. This strategy has been developed to circumvent side effects of the conventional intravenous therapy with prostacyclin, e.g. systemic hypotension and ventilation-perfusion mismatch. As anticipated from previous studies in patients with severe pulmonary hypertension $[4,5]$, aerosolization of iloprost was, indeed, effective in causing lung vasorelaxation without any decrease in systemic arterial pressure and any deterioration of gas exchange in the present rabbit model. After completion of the aerosolization maneuver, the iloprost effect levelled off within $20-30 \mathrm{~min}$, which is somewhat more rapid than in the human system (45-90 $\mathrm{min})$. This difference is most likely due to some species variance in the kinetics of the iloprost catabolic pathway: being chemically stable in contrast to prostacyclin - iloprost is converted to dinorand tetranor-iloprost metabolites via beta-oxidation [25]. The liver is known to be a major site of this catabolic pathway, however, recent studies in isolated perfused rabbit lungs demonstrated that the conversion of iloprost to these beta-oxidation products also takes place in the lung tissue itself [26].

Phosphodiesterases represent the major route for cAMP and cGMP degradation in cells, thereby limiting the downstream effects of adenylate and guanylate cyclase activating agents such as prostacyclin or NO. Until now, 11 types of PDEs have been characterized, which differ in substrate specificity and regulatory properties $[9,27,28]$. Within the lung, PDE 3 and 4 represent the major cAMP hydrolyzing pathways [10], and monoselective inhibitors of PDE 3 and PDE 4 have been shown to possess pulmonary vasodilatory potency $[8,11,29]$.

Motapizone is a highly selective PDE3 inhibitor, with an $\mathrm{IC}_{50}$ value of $30 \mathrm{nM}$ [30]. Thus, the finding that motapizone infusion causes dose-dependent pulmonary 

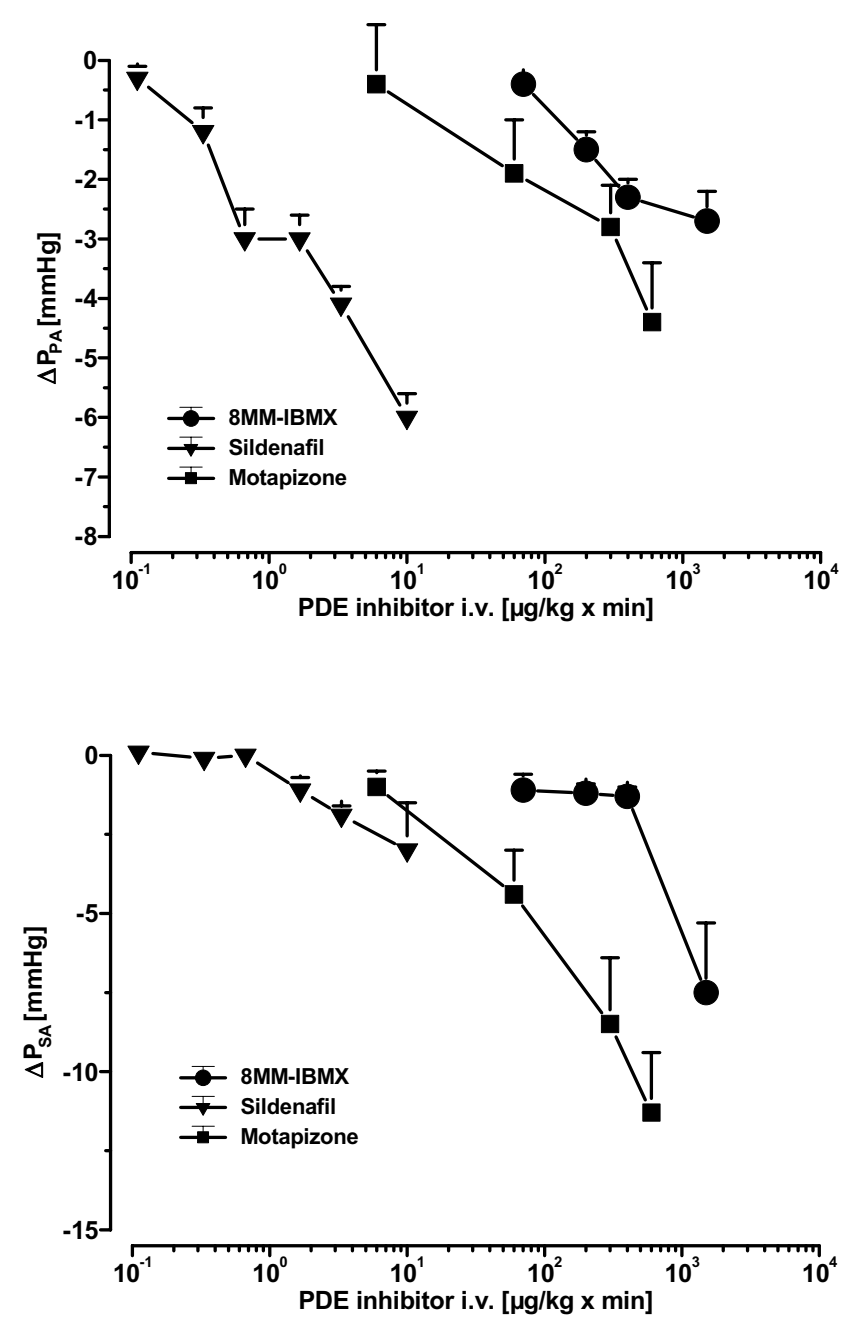

Figure I

Dose effect curves of different PDE inhibitors on U466 19elicited pulmonary hypertension (a) and systemic arterial pressure (b). (a) Pulmonary artery pressure drop $\left(\Delta \mathrm{P}_{\mathrm{PA}}\right.$, in $\mathrm{mmHg})$ and systemic arterial pressure drop $\left(\Delta \mathrm{P}_{\mathrm{SA}}\right.$, in $\left.\mathrm{mmHg}\right)$ (b) are given (mean \pm SEM of 6 independent experiments each). PDE-inhibitors were applied in different doses as short-term infusion.
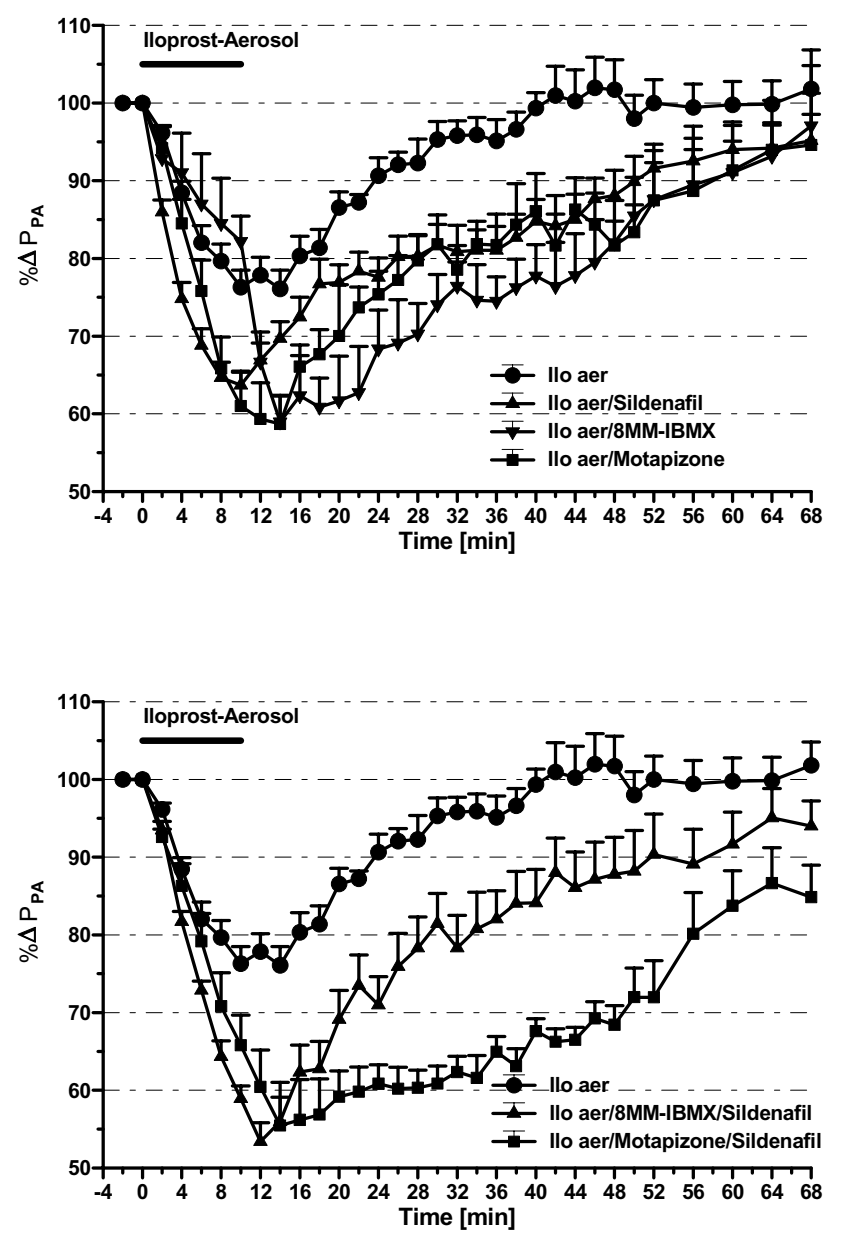

Figure 2

Influence of iloprost nebulization and its combination with sub-threshold doses of single (a) or combined (b) intravenous PDE inhibitors on U46619-elicted pulmonary hypertension. Pulmonary artery pressure $\left(P_{P A}\right.$, in \% of U466 I9induced increase) is given (mean \pm SEM of 8 independent experiments each, SEM bars are missing when falling into symbol). lloprost nebulization (Ilo aer; $0.4 \mu \mathrm{g} / \mathrm{kg}$ ) is indicated by the horizontal bar. The PDE inhibitors were pre-applied as short-term infusion as follows: $200 \mu \mathrm{g} / \mathrm{kg} \times \mathrm{min}$ 8-Methoxymethyl-IBMX, I $\mu \mathrm{g} / \mathrm{kg} \times \min$ sildenafil, $5 \mu \mathrm{g} / \mathrm{kg} \times \mathrm{min}$ motapizone. vasodilatation in intact rabbits with elevated pulmonary artery pressure is well in line with previous observations in this field. Notably, the motapizone effect was not pulmonary selective: in the dose range from 10 to $1000 \mu \mathrm{g} / \mathrm{kg}$ $\times$ min, both the pulmonary artery and the systemic artery pressure declined in a parallel fashion.

PDE1 gene products are expressed in cardiac tissues from several species [31,32]. A role of increased PDE1C expression in the cardio-protective effect of the stable prostacyclin derivative, 7-oxo-prostacyclin, indicates that PDE1C variants may be involved in tissue responses to cardiovascular stress [33]. In vascular smooth muscle cells derived from different species, several reports demonstrated PDE1 expression. PDE1C was shown to be present in proliferating smooth muscle cells [31,34] and an increased expression of PDE1A1 in rat aorta was shown to 


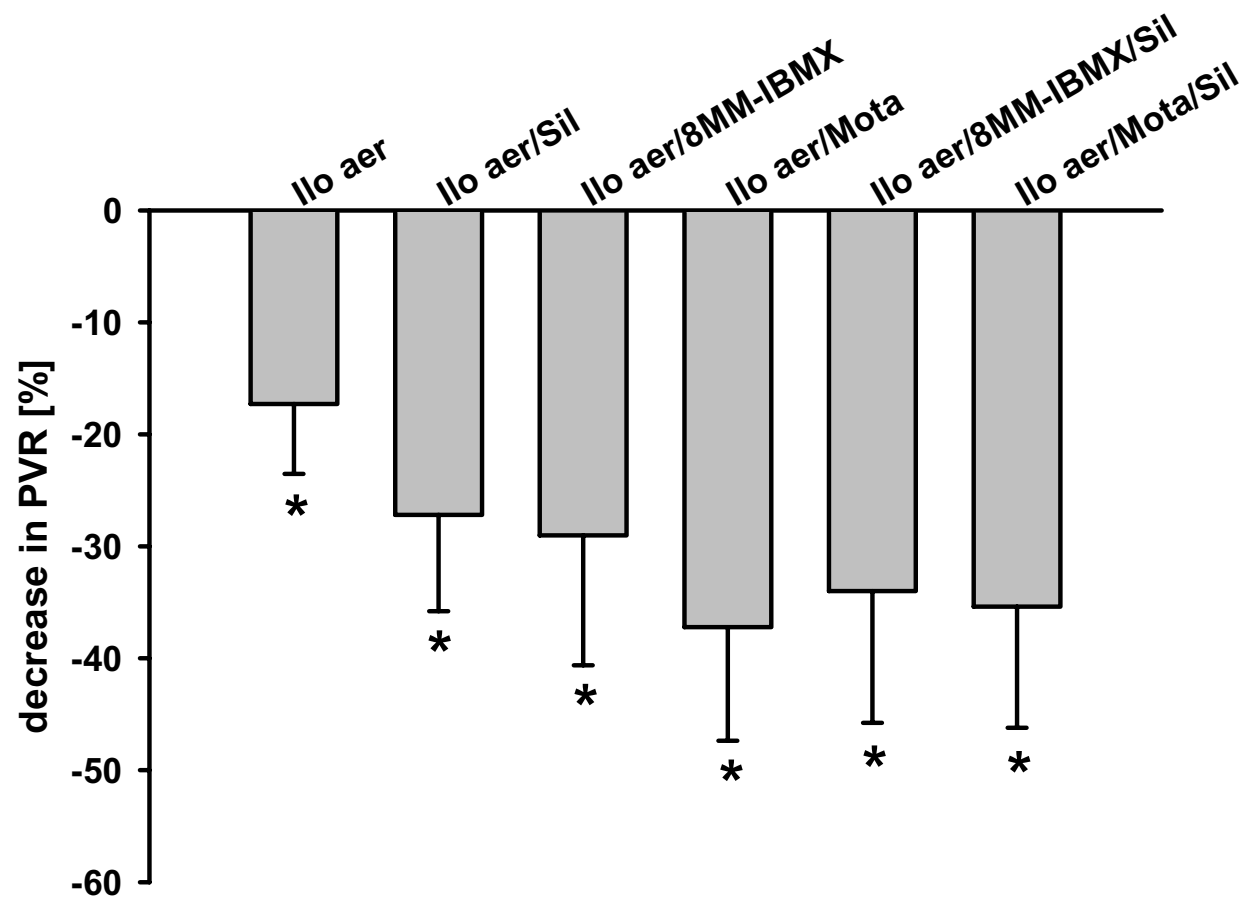

\section{Figure 3}

Influence of iloprost nebulization and its combination with sub-threshold doses of intravenous PDE inhibitors on U466I9elicted pulmonary hypertension. Decrease in pulmonary vascular resistance (PVR, in \%) at the end of the nebulization period is given (mean \pm SEM of 8 independent experiments each). The PDE inhibitors were pre-applied as short-term infusion as follows: $200 \mu \mathrm{g} / \mathrm{kg} \times \min 8-M e t h o x y m e t h y l-I B M X, I \mu g / k g \times \min$ sildenafil, $5 \mu \mathrm{g} / \mathrm{kg} \times$ min motapizone. *, $\mathrm{p}<0.05$ as compared to pre-nebulization value.

contribute to the development of nitroglycerin tolerance [35].

Concerning the lung vasculature, only very limited data on PDE1 expression is available [11]. Our group recently observed that PDE1C is strongly upregulated in the pulmonary artery media of human lungs with severe pulmonary hypertension (R. Schermuly et al., non-published results). It is in line with this notion that the selective PDE1 inhibitor 8MM-IBMX induced dose-dependent pulmonary vasodilation in the presently investigated acute pulmonary hypertension model, however, without being specific for the pulmonary circulation, as evident from the parallel decline of systemic arterial pressure.
The cGMP-specific phosphodiesterase PDE 5 is abundantly distributed in the lung tissue $[13,14,36]$. In a hypoxia-induced model of pulmonary hypertension in the rat, Cohen et al. demonstrated that the PDE 5 inhibitor E4021 selectively vasodilates the pulmonary circulation when being applied intravenously [36], and this observation was confirmed in a model of newborn lambs with persistent pulmonary hypertension [37]. Another specific PDE 5 inhibitor, E4010, has been shown to be a selective pulmonary vasodilatator in a hypoxic rat model of pulmonary hypertension [38]. Accordingly, the PDE 1/ $5 / 6$ inhibitor sildenafil, which is approved for treatment of erectile dysfunction, was also recently shown to cause preferential pulmonary vasodilatation even when being systemically administered [39]. These data are well in line 


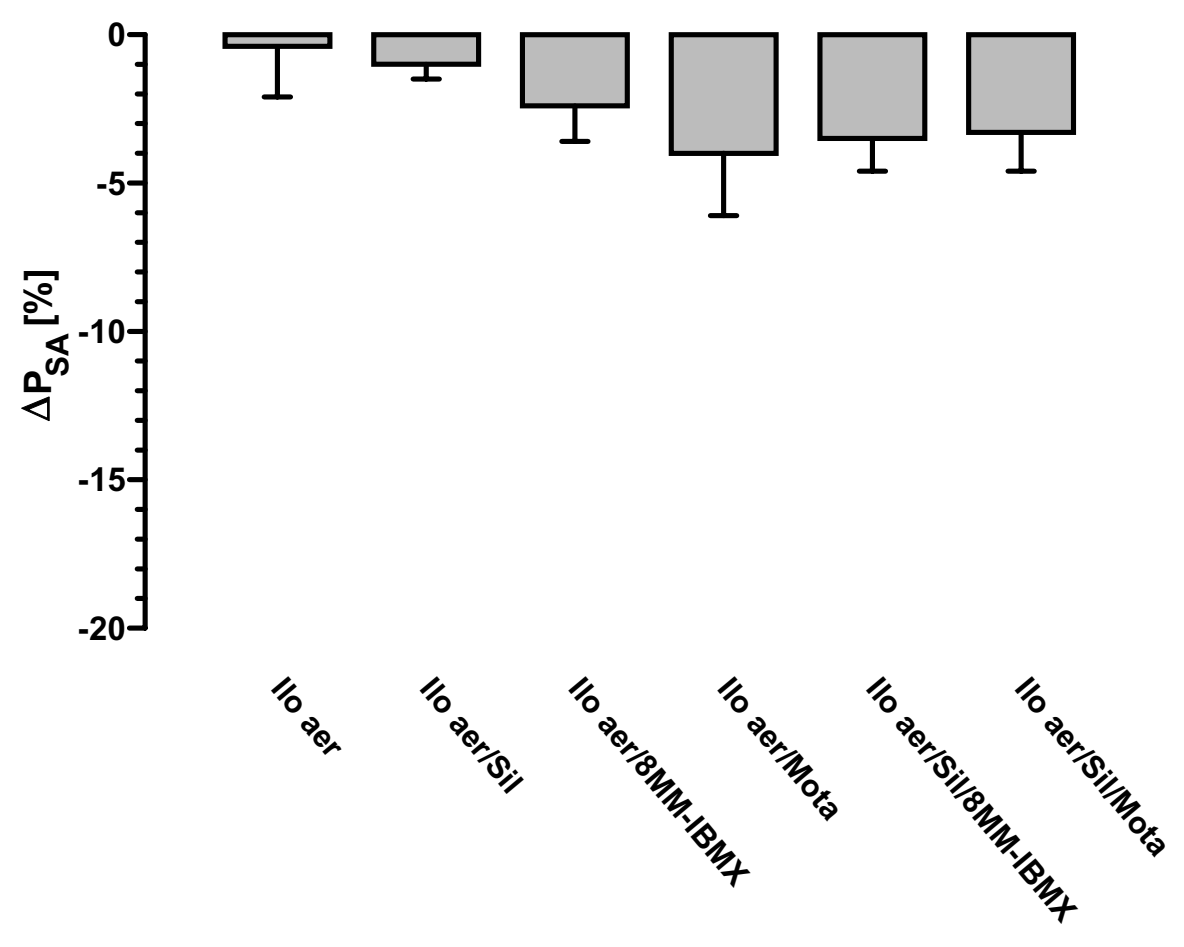

\section{Figure 4}

Influence of iloprost nebulization and its combination with sub-threshold doses of single or combined intravenous PDE inhibitors on systemic arterial pressure $\left(P_{S A}\right)$. The experiments correspond to those in Fig. 2; the decrease in $P_{S A}$ (in \% of baseline) at the end of the iloprost nebulization (llo aer) period is given (mean \pm SEM of 8 independent experiments each).

with the current finding in pulmonary hypertensive rabbits that intravenously infused sildenafil causes a dosesdependent decrease in pulmonary artery pressure, virtually without any decline in systemic arterial pressure.

The rationale to combine cAMP-elevating agents, like prostacyclin or the stable prostacyclin analogue iloprost, with PDE3 inhibitors is obvious, and studies from our group already showed a marked amplification and prolongation of the pulmonary vasodilatory response to aerosolized prostacyclin in the presence of type $3 \mathrm{PDE}$ inhibitors $[8,29]$. The present investigation demonstrates that such synergistic effect also hold true for the PDE3 inhibitor motapizone and the longer acting agent ilo- prost: in the presence of minute doses of intravenously applied motapizone, the area under the curve of $\mathrm{P}_{\mathrm{PA}}$ decrease in response to the standard inhaled iloprost dose was nearly threefold increased, again without any decline in systemic arterial pressure or any deterioration of gas exchange being detectable.

Interestingly, similar potency to increase the response to inhaled iloprost was also noted for subthreshold doses of the PDE 1 inhibitor 8MM-IBMX. This might be anticipated to some extent, as PDE1 causes degradation of both cAMP and cGMP (Fig. 6), thereby directly effecting downstream signalling of iloprost, and indirectly modifying this pathway via CGMP sensitive PDE inhibitors. The 


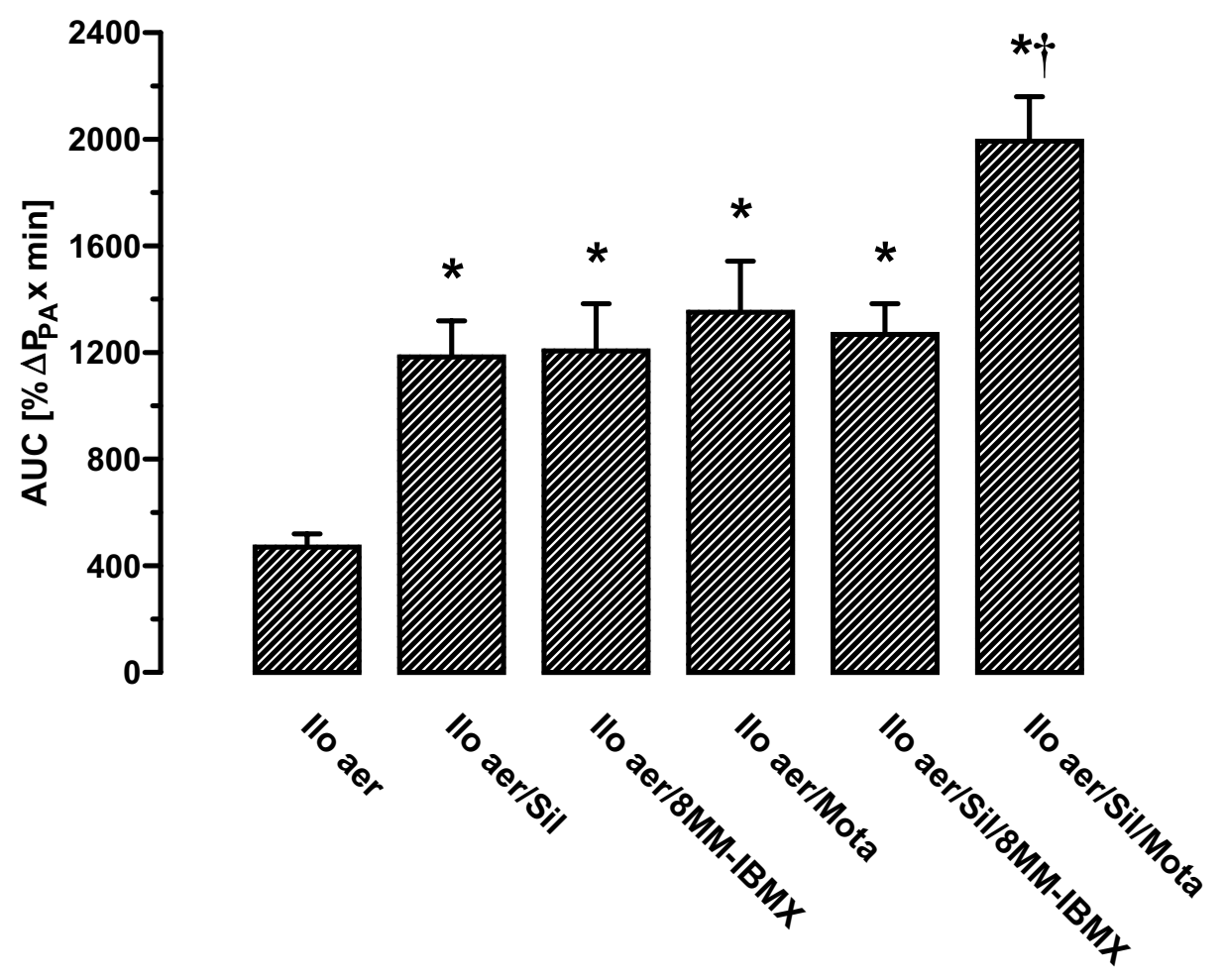

\section{Figure 5}

Influence of PDE inhibition on the area under the curve (AUC) of iloprost-induced decrease in pulmonary artery pressure $\left(\mathrm{P}_{\mathrm{PA}}\right)$. Measurements were performed from onset of iloprost nebulization (llo aer) until 68 min post aerosolization. AUC was calculated by standard techniques and is given as $\% \Delta \mathrm{P}_{\mathrm{PA}} \times \min$. The maneuvers and dosages correspond to those depicted in Fig. 2. *, $p<0.05$ as compared to sole iloprost nebulization; $\dagger, p<0.05$ as compared to all other groups.

fact, however, that the area under the curve of PPA reduction was similarly augmented as in the presence of motapizone ( threefold) suggests that PDE1 inhibitors are worth to be taken into consideration for further strategies to enhance beneficial prostanoid effects in the pulmonary circulation.

Furthermore, the current study demonstrates that the PDE $1 / 5 / 6$ inhibitor sildenafil also amplifies the pulmonary vasodilatory response to inhaled iloprost, and that in this respect subthreshold systemic doses of sildenafil are again virtually as effective as subthreshold doses of the PDE3 inhibitor motapizone. This amplification of the iloprostinduced $\mathrm{P}_{\mathrm{PA}}$ decrease again occurred without any decline in systemic arterial pressure and any gas exchange distur- bances. The mechanisms underlying this sildenafil effect deserve further elucidation. Given the pharmacological profile of this agent $[40,41]$, it is unlikely that sildenafil caused relevant direct inhibition of lung PDE 3 and 4, thereby promoting prolongation of the half life of cAMP. Its effect may, however, well be explained by the known cross talk between the CAMP and the cGMP pathways: PDE 3 is inhibited by intracellular cGMP with an $\mathrm{IC}_{50}$ of 0.1-1 $\mu \mathrm{M}$ [42]. A significant inhibition of PDE 5 by sildenafil may thus result in CGMP accumulation, given the fact that there is some permanent baseline stimulation of this pathway via endogenous $\mathrm{NO}$, and next to causing per se some vasodilatory effect, the sildenafil-induced cGMP may particularly be effective via PDE 3 inhibition and thereby enhanced sensitivity to inhaled iloprost. In 


\section{lloprost}

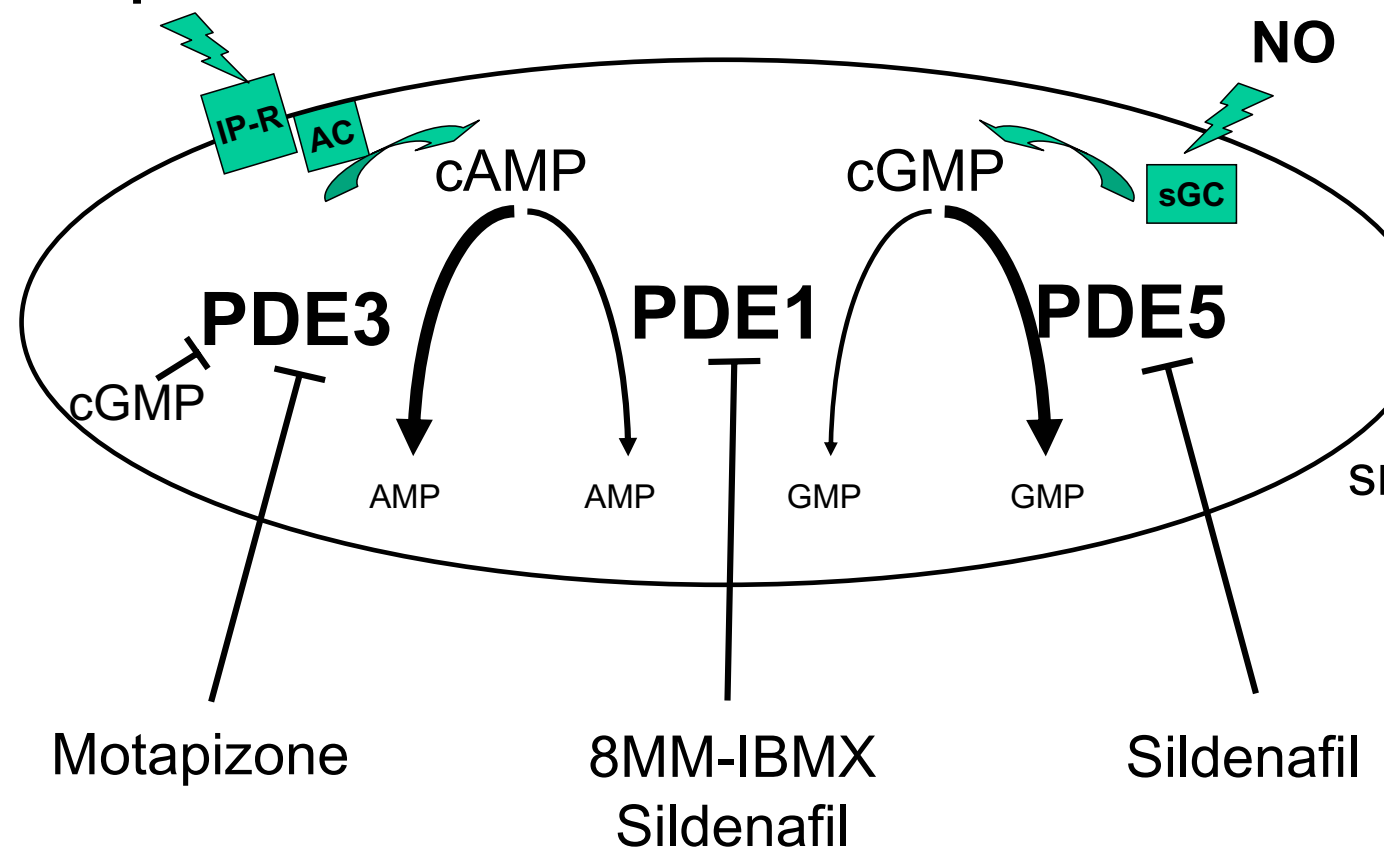

Figure 6

Schematic depiction of the crosstalk between different phosphodiesterases (PDE) and the effects of PDE inhibitors on cGMP and CAMP signaling. Different agonists, e.g. prostanoids or nitric oxide (NO) increase the intracellular concentrations of the second messengers cyclic adenosine monophosphate (cAMP) and guanosine monophosphate (cGMP). Phosphodiesterase (PDE) inhibitors stabilize the second messengers and amplify the efficacy of the agonists. 8MM-IBMX selectively blocks PDEI which can hydrolyze both cyclic nucleotides. Motapizone inhibits PDE3, which hydrolyzes cAMP and is inhibitable by cGMP. Sildenafil blocks PDE5 and PDEI and can therefore influence the CAMP and cGMP pathway. IP-R, prostacyclin receptor; AC, adenylate cyclase; sGC, soluble guanylate cyclase; smc, smooth muscle cell; PDE, phosphodiesterase.

addition to such mode of action, supported by previous studies in the cooperativity between the cGMP and the cAMP axis in the lung vasculature $[8,43]$, further (noncGMP related) effects of sildenafil in the pulmonary circulation may involve inhibition of PDE1 (Fig. 5). This view is supported by the above discussed efficacy of selective PDE1 inhibition by 8-MM-IBMX. The $\mathrm{IC}_{50}$ of sildenafil against PDE1 is about $280 \mathrm{nM}$ [15], and although plasma levels of sildenafil are not addressed in this study, these levels could be achieved after sildenafil application.

Thus, both indirect inhibition of PDE3 by increased cGMP and direct inhibition of PDE1 may explain the effects of sildenafil on the iloprost-induced vasodilation. Our studies in co-application of sildenafil with motapizone on the one hand and 8-MM-IBMX on the other hand do, however, favour the sildenafil-PDE1 axis: whereas the combination of sildenafil with the PDE1 inhibitor 8MMIBMX did not further amplify the iloprost-induced vasodi- lation over the effect of each agent alone, the combination of sildenafil plus motapizone effected a further strong amplification of the prostanoid induced vasodilation. Besides being of interest as to the mode of action of sildenafil, this finding suggests that an optimum strategy to combine PDE inhibitors may result in even further augmentation of pulmonary vascular prostanoid efficacy as compared to the choice of one selective PDE inhibitor as partner for the prostanoid. In conclusion, intravenous administration of the PDE1 inhibitor $8 \mathrm{MM}$-IBMX, the PDE 3 inhibitor motapizone and the PDE 1/5/6 inhibitor sildenafil causes dose-dependent pulmonary vasodilation in a rabbit model of pulmonary hypertension, with sildenafil possessing selectivity for the lung vasculature. Most interestingly, when applied in subthreshold doses, all PDE inhibitors enhanced and markedly prolonged the vasodilatory response to inhaled iloprost, without any systemic pressure decline or deterioration of gas exchange being detectable. Maximum efficacy was noted upon com- 
bination of sildenafil and motapizone. Combination of low dose systemic PDE inhibitors might thus be considered for enhancement and in particular prolongation of the lung vasorelaxant response to inhaled iloprost.

\section{Abbreviations}

$\mathrm{P}_{\mathrm{PA}^{\prime}}$ mean pulmonary artery pressure; $\mathrm{P}_{\mathrm{SA}^{\prime}}$ mean aortic pressure; CO, cardiac output; U46619, stable thromboxane- $\mathrm{A}_{2}$ analogue; PDE, phosphodiesterase; Mota, motapizone; Sil, sildenafil; Ilo, iloprost.

\section{Acknowledgements}

This work was supported by the Deutsche Forschungsgemeinschaft (SFB 547), Project C6.

\section{References}

I. Barst RJ, Rubin LJ, Long WA, McGoon MD, Rich S, Badesch DB, Groves BM, Tapson VF, Bourge RC, Brundage BH: A comparison of continuous intravenous epoprostenol (prostacyclin) with conventional therapy for primary pulmonary hypertension. The Primary Pulmonary Hypertension Study Group [see comments]. N Engl J Med 1996, 334:296-302.

2. D'Alonzo GE, Barst RJ, Ayres SM, Bergofsky EH, Brundage BH, Detre KM, Fishman AP, Goldring RM, Groves BM, Kernis JT: Survival in patients with primary pulmonary hypertension. Results from a national prospective registry. Ann Intern Med 1991, I I 5:343-349.

3. Rubin LJ, Mendoza J, Hood M, McGoon M, Barst R, Williams WB, Diehl JH, Crow J, Long W: Treatment of primary pulmonary hypertension with continuous intravenous prostacyclin (epoprostenol). Results of a randomized trial. Ann Intern Med 1990, I I 2:485-49|.

4. Hoeper MM, Olschewski H, Ghofrani HA, Wilkens H, Winkler J, Borst MM, Niedermeyer J, Fabel H, Seeger W: A comparison of the acute hemodynamic effects of inhaled nitric oxide and aerosolized iloprost in primary pulmonary hypertension. German PPH study group. J Am Coll Cardiol 2000, 35: I76-I82.

5. Olschewski H, Walmrath D, Schermuly R, Ghofrani A, Grimminger F, Seeger W: Aerosolized prostacyclin and iloprost in severe pulmonary hypertension. Ann Intern Med 1996, I 24:820-824.

6. Olschewski H, Ghofrani HA, Schmehl T, Winkler J, Wilkens H, Hoper MM, Behr J, Kleber FX, Seeger W: Inhaled iloprost to treat severe pulmonary hypertension. An uncontrolled trial. German PPH Study Group [see comments]. Ann Intern Med 2000, 132:435-443.

7. Olschewski H, Simonneau G, Galie N, Higenbottam T, Naeije R, Rubin LJ, Nikkho S, Speich R, Hoeper MM, Behr J, et al:: Inhaled iloprost for severe pulmonary hypertension. N Engl J Med 2002, 347:322-329.

8. Schermuly RT, Ghofrani HA, Enke B, Weissmann N, Grimminger F, Seeger W, Schudt C, Walmrath D: Low-dose systemic phosphodiesterase inhibitors amplify the pulmonary vasodilatory response to inhaled prostacyclin in experimental pulmonary hypertension. Am J Respir Crit Care Med 1999, 160:1500-1506.

9. Manganiello VC, Murata T, Taira M, Belfrage P, Degerman E: Diversity in cyclic nucleotide phosphodiesterase isoenzyme families. Arch Biochem Biophys 1995, 322:I-I3.

10. Torphy TJ: Phosphodiesterase isozymes: molecular targets for novel antiasthma agents. Am J Respir Crit Care Med 1998, I57:35I-370.

II. Rabe KF, Tenor H, Dent G, Schudt C, Nakashima M, Magnussen H: Identification of PDE isozymes in human pulmonary artery and effect of selective PDE inhibitors. Am J Physiol 1994, 266:L536-L543.

12. Beavo JA: Cyclic nucleotide phosphodiesterases: functional implications of multiple isoforms. Physiol Rev 1995, 75:725-748.

13. Giordano D, De Stefano ME, Citro G, Modica A, Giorgi M: Expression of cGMP-binding cGMP-specific phosphodiesterase (PDE5) in mouse tissues and cell lines using an antibody against the enzyme amino-terminal domain. Biochim Biophys Acta 200I, I539:16-27.
14. Hanson KA, Burns F, Rybalkin SD, Miller JW, Beavo J, Clarke WR: Developmental changes in lung CGMP phosphodiesterase-5 activity, protein, and message. Am J Respir Crit Care Med 1998, I 58:279-288.

15. Gresser U, Gleiter $\mathrm{CH}$ : Erectile dysfunction: comparison of efficacy and side effects of the PDE-5 inhibitors sildenafil, vardenafil and tadalafil - review of the literature. Eur J Med Res 2002, 7:435-446.

16. Ghofrani HA, Wiedemann R, Rose F, Olschewski H, Schermuly RT, Weissmann N, Seeger W, Grimminger F: Combination therapy with oral sildenafil and inhaled iloprost for severe pulmonary hypertension. Ann Intern Med 2002, 136:51 5-522.

17. Ghofrani HA, Voswinckel R, Reichenberger F, Olschewski H, Haredza P, Karadas B, Schermuly RT, Weissmann N, Seeger W, Grimminger $F$ : Differences in hemodynamic and oxygenation responses to three different phosphodiesterase-5 inhibitors in patients with pulmonary arterial hypertension: a randomized prospective study. I Am Coll Cardiol 2004, 44: |488-| 496.

18. Ghofrani HA, Rose F, Schermuly RT, Olschewski H, Wiedemann R, Kreckel A, Weissmann N, Ghofrani S, Enke B, Seeger W, et al.: Oral sildenafil as long-term adjunct therapy to inhaled iloprost in severe pulmonary arterial hypertension. J Am Coll Cardiol 2003, 42:158-164.

19. Ghofrani HA, Schermuly RT, Rose F, Wiedemann R, Kohstall MG, Kreckel A, Olschewski H, Weissmann N, Enke B, Ghofrani S, et al: Sildenafil for long-term treatment of nonoperable chronic thromboembolic pulmonary hypertension. Am J Respir Crit Care Med 2003, 167:II39-II4I.

20. Ghofrani HA, Wiedemann R, Rose F, Schermuly RT, Olschewski H, Weissmann N, Gunther A, Walmrath D, Seeger W, Grimminger F: Sildenafil for treatment of lung fibrosis and pulmonary hypertension: a randomised controlled trial. Lancet 2002, 360:895-900.

21. Prasad S, Wilkinson J, Gatzoulis MA: Sildenafil in primary pulmonary hypertension. N Engl J Med 2000, 343: I 342 .

22. Wilkens H, Guth A, Konig J, Forestier N, Cremers B, Hennen B, Bohm M, Sybrecht GW: Effect of inhaled iloprost plus oral sildenafil in patients with primary pulmonary hypertension. Circulation 200I, 104:I2I8-I222.

23. Schermuly RT, Weissmann N, Enke B, Ghofrani HA, Forssmann WG Grimminger F, Seeger W, Walmrath D: Urodilatin, a natriuretic peptide stimulating particulate guanylate cyclase, and the phosphodiesterase 5 inhibitor dipyridamole attenuate experimental pulmonary hypertension: synergism upon coapplication. Am J Respir Cell Mol Biol 200I, 25:219-225.

24. Schermuly R, Schmehl T, Gunther A, Grimminger F, Seeger W, Walmrath $D$ : Ultrasonic nebulization for efficient delivery of surfactant in a model of acute lung injury. Impact on gas exchange. Am J Respir Crit Care Med 1997, I 56:445-453.

25. Krause W, Humpel M, Hoyer GA: Biotransformation of the stable prostacyclin analogue, iloprost, in the rat. Drug Metab Dispos 1984, I 2:645-65I.

26. Schermuly RT, Schulz A, Ghofrani HA, Meidow A, Rose F, Roehl A Weissmann N, Hildebrand M, Kurz J, Grimminger F, et al:: Pharmacokinetics and Metabolism of Infused versus Inhaled Iloprost in Isolated Rabbit Lungs. J Pharmacol Exp Ther 2002, 303:74I -745.

27. Fawcett L, Baxendale R, Stacey P, McGrouther C, Harrow I, Soderling S, Hetman J, Beavo JA, Phillips SC: Molecular cloning and characterization of a distinct human phosphodiesterase gene family: PDE I IA. Proc Natl Acad Sci U S A 2000, 97:3702-3707.

28. Soderling SH, Bayuga SJ, Beavo JA: Isolation and characterization of a dual-substrate phosphodiesterase gene family: PDEIOA. Proc Natl Acad Sci U S A 1999, 96:707I-7076.

29. Schermuly RT, Roehl A, Weissmann N, Ghofrani HA Schudt C Tenor H, Grimminger F, Seeger W, Walmrath D: Subthreshold doses of specific phosphodiesterase type 3 and 4 inhibitors enhance the pulmonary vasodilatory response to nebulized prostacyclin with improvement in gas exchange. J Pharmacol Exp Ther 2000, 292:512-520.

30. Rabe KF, Tenor H, Dent G, Schudt C, Liebig S, Magnussen H: Phosphodiesterase isozymes modulating inherent tone in human airways: identification and characterization. Am J Physiol 1993 , 264:L458-L464.

31. Rybalkin SD, Bornfeldt KE, Sonnenburg WK, Rybalkina IG, Kwak KS, Hanson K, Krebs EG, Beavo JA: Calmodulin-stimulated cyclic nucleotide phosphodiesterase (PDEIC) is induced in human 
arterial smooth muscle cells of the synthetic, proliferative phenotype. J Clin Invest 1997, 100:26 I I-262I.

32. Zhao AZ, Yan C, Sonnenburg WK, Beavo JA: Recent advances in the study of $\mathrm{Ca2}+/ \mathrm{CaM}$-activated phosphodiesterases: expression and physiological functions. Adv Second Messenger Phosphoprotein Res 1997, 31:237-25I.

33. Kostic MM, Erdogan S, Rena G, Borchert G, Hoch B, Bartel S, Scotland G, Huston E, Houslay MD, Krause EG: Altered expression of PDEI and PDE4 cyclic nucleotide phosphodiesterase isoforms in 7-oxo-prostacyclin-preconditioned rat heart. J Mol Cell Cardiol 1997, 29:3।35-3146.

34. Rybalkin SD, Rybalkina I, Beavo JA, Bornfeldt KE: Cyclic nucleotide phosphodiesterase IC promotes human arterial smooth muscle cell proliferation. Circ Res 2002, 90:15I-157.

35. Kim D, Rybalkin SD, Pi X, Wang Y, Zhang C, Munzel T, Beavo JA, Berk BC, Yan C: Upregulation of phosphodiesterase IAI expression is associated with the development of nitrate tolerance. Circulation 200I, 104:2338-2343.

36. Cohen AH, Hanson K, Morris K, Fouty B, McMurty IF, Clarke W, Rodman DM: Inhibition of cyclic 3'-5'-guanosine monophosphate-specific phosphodiesterase selectively vasodilates the pulmonary circulation in chronically hypoxic rats. J Clin Invest 1996, 97:172-179.

37. Dukarm RC, Russell JA, Morin FC III, Perry BJ, Steinhorn RH: The cGMP-specific phosphodiesterase inhibitor E402I dilates the pulmonary circulation. Am J Respir Crit Care Med 1999, 160:858-865.

38. Hanasato N, Oka M, Muramatsu M, Nishino M, Adachi H, Fukuchi Y: E-40 I 0 , a selective phosphodiesterase 5 inhibitor, attenuates hypoxic pulmonary hypertension in rats. Am J Physiol 1999, 277:L225-L232.

39. Weimann J, Ullrich R, Hromi J, Fujino Y, Clark MW, C B, Bloch KD, Zapol WM: Sildenafil is a pulmonary vasodilator in awake lambs with acute pulmonary hypertension. Anesthesiology 2000, 92:1702-17|2.

40. Boolell M, Allen MJ, Ballard SA, Gepi-Attee S, Muirhead GJ, Naylor AM, Osterloh IH, Gingell C: Sildenafil: an orally active type 5 cyclic GMP-specific phosphodiesterase inhibitor for the treatment of penile erectile dysfunction. Int J Impot Res 1996, 8:47-52.

41. Wallis RM, Corbin JD, Francis SH, Ellis P: Tissue distribution of phosphodiesterase families and the effects of sildenafil on tissue cyclic nucleotides, platelet function, and the contractile responses of trabeculae carneae and aortic rings in vitro. Am J Cardiol 1999, 83:3C-12C.

42. Torphy TJ, Undem BJ: Phosphodiesterase inhibitors: new opportunities for the treatment of asthma. Thorax |991, 46:5I 2-523.

43. Eckly AE, Lugnier C: Role of phosphodiesterases III and IV in the modulation of vascular cyclic AMP content by the NO/ cyclic GMP pathway. Br J Pharmacol I 994, I I 3:445-450.
Publish with Biomed Central and every scientist can read your work free of charge

"BioMed Central will be the most significant development for disseminating the results of biomedical research in our lifetime. "

Sir Paul Nurse, Cancer Research UK

Your research papers will be:

- available free of charge to the entire biomedical community

- peer reviewed and published immediately upon acceptance

- cited in PubMed and archived on PubMed Central

- yours - you keep the copyright
BioMedcentral 